\title{
OS MECANISMOS DE CONSENSO E COERÇÃO EM TORNO DO PROJETO DE DESENVOLVIMENTO HEGEMÔNICO NO AMAPÁ1
}

\author{
THE MECHANISMS OF CONSENSUS AND COERCTION AROUND \\ THE HEGEMONIC DEVELOPMENT PROJECT IN AMAPÁ
}

Eduardo Margarit Alfena do Carmo1
\[ \underline{\text { https://orcid.org/0000-0002-7118-106X }} \]
$\underline{\text { http://lattes.cnpq.br/9106331944059097 }}$

\section{Celene Cunha Monteiro Antunes Barreira² \\ https://orcid.org/0000-0003-1463-1471 http://lattes.cnpq.br/1038300875963340}

Cleuton Pinto Miranda ${ }^{3}$

https://orcid.org/0000-0003-0696-2406 http://lattes.cnpq.br/4354921036456998

Recebido em: 3 de abril de 2020.

Aprovado em: 8 de junho de 2020.

\begin{abstract}
RESUMO: O objetivo deste artigo é evidenciar as estratégias de introdução do projeto de desenvolvimento hegemônico no Amapá. A metodologia da pesquisa foi baseada na compreensão dos mecanismos de consenso e coerção do Estado em torno do projeto de desenvolvimento hegemônico, tendo como fonte de dados primários entrevistas com os povos afetados pelos empreendimentos do grande capital. Como resultado, foi possível constatar que há uma estratégia de publicidade que envolve slogans, propagandas governamentais, além dos discursos de parlamentares, governantes e empresários na mídia, que (re)produzem o discurso hegemônico. Dominam também neste cenário as estratégias de coerção e violência contra povos tradicionais, movimentos sociais e entidades representativas dos interesses destes povos, em um claro cenário de violação dos mecanismos democráticos. Palavras-chave: Amazônia; Capitalismo; Infraestrutura; Povos Tradicionais.
\end{abstract}

\footnotetext{
1 Professor do Curso de Licenciatura em Geografia do Campus Binacional de Oiapoque, da Universidade Federal do Amapá - UNIFAP, desde 2013. Graduado em Geografia pela Universidade Federal Fluminense - UFF (2010), Mestre em Geografia pela Universidade Federal de Mato Grosso do Sul - UFMS (2012) e Doutor em Geografia pela Universidade Federal de Goiás - UFG (2019). E-mail: eduardo.margarit@unifap.br.

2 Professora Titular na Universidade Federal de Goiás no Instituto de Estudos Socioambientais- IESA (2014- 2018). Integra o corpo docente do Programa de Pesquisa e Pós-Graduação em Geografia (doutorado e mestrado) do IESA/UFG. Fez parte da equipe de Avaliação da Pós-graduação da CAPES, na área de Geografia entre 2010-2014. Possui graduação em Geografia pela Universidade Federal de Goiás (1978), mestrado em História pela Universidade Federal de Goiás (1989) e doutorado em Geografia (Geografia Humana) pela Universidade de São Paulo (1997). E-mail: celenemonteiro05@gmail.com.

${ }^{3}$ Graduando em Geografia no Campus Binacional de Oiapoque da Universidade Federal do Amapá (UNIFAP). E-mail: cmmiranda1995@hotmail.com.
} 
ABSTRACT: The purpose of this article is to highlight the strategies for introducing the hegemonic development project in Amapá. The research methodology was based on the understanding of the State's consensus and coercion mechanisms around the hegemonic development project, having as primary data source interviews with the people affected by the great capital enterprises. As a result, it was possible to verify that there is an publicity strategy that involves slogans, government commercials, in addition to the speech in media of parliamentarians, government officials and businessmen, who (re)make the hegemonic speech. In this scenario, also dominate coercion and violence strategies against traditional peoples, social movements and entities representing the interests of these peoples, in a clear scenario of democratic mechanisms violation.

Key-words: Amazon; Capitalism; Infrastructure; Traditional Peoples.

\section{INTRODUÇÃO}

O estado do Amapá é uma unidade da federação relativamente nova, criada com a Constituição Brasileira de 1988, a partir do Território Federal do Amapá criado em 1943. Sua criação está relacionada com a grande relevância geopolítica desta porção territorial para o Brasil, por estar localizada entre a foz do Rio Amazonas e a fronteira com a Guiana Francesa. Apesar da relevância geopolítica, o Amapá permaneceu durante o século XX relativamente isolado da dinâmica econômica do restante do País, devido à precária infraestrutura de circulação, incapaz de dotar o território da fluidez necessária ao desenvolvimento do capitalismo.

Com a implantação do Programa de Aceleração do Crescimento (PAC), em 2007, teve início diversas obras de infraestrutura no Amapá capazes de consolidar a integração territorial competitiva do estado. O asfaltamento de rodovias, a construção de usinas hidrelétricas, a conexão do estado com o Sistema Interligado Nacional (SIN) de energia, a construção da Ponte Binacional entre o Amapá e a Guiana Francesa, o desenvolvimento do complexo portuário de Santana e a construção de um novo terminal de passageiros no aeroporto de Macapá, são as principais obras de infraestrutura de grande envergadura desenvolvidas no âmbito do Pac no Amapá.

As obras de infraestrutura do Pac consolidaram as redes técnicas necessárias ao desenvolvimento do capitalismo e a apropriação dos bens naturais disponíveis, como as terras, os minérios, os rios, as matas, entre outros. Diante desta condição houve a ascensão da mineração, do agronegócio, da indústria madeireira, da indústria pesqueira e da indústria petrolífera, tidos como grandes projetos de desenvolvimento do Amapá. Como consequência da implantação e crescimento destes grandes projetos capitalistas, ocorre um processo de reordenamento territorial no Amapá, que passa a se configurar dentro da lógica de reprodução destas atividades.

Portanto, com o desenvolvimento do capitalismo no Amapá, proporcionado pelas grandes obras de infraestrutura, surge como problemática a contradição existente entre a organização territorial do capitalismo e a dos povos tradicionais. A introdução de uma nova lógica da organização territorial aos interesses do mercado, capitais, exportação e agronegócio, vêm desestruturando o modo de vida dos povos tradicionais e gerando conflitos territoriais.

Esta nova racionalidade no ordenamento territorial do Amapá é fruto de um modelo de desenvolvimento, ligado à lógica de reprodução do capitalismo global. Este modelo de desenvolvimento vem se perpetuando com estratégias que visam a manutenção do poder e da con- 
centração da renda das elites, por meio do aparato estatal e suas políticas públicas, que garantam a perpetuação deste arranjo político-econômico, assumindo características hegemônicas.

Para dar suporte a esta estratégia de desenvolvimento há um complexo aparato político mobilizado para influenciar decisões e convencer a opinião pública da necessidade de continuidade de tais empreendimentos. Baseado no discurso de que as grandes obras de infraestrutura no Amapá são indispensáveis para o desenvolvimento do País, o Estado forja uma ideia equivocada da imperiosa necessidade na execução destas obras, qualificando os empreendimentos e reduzindo as críticas a partir de um discurso que exalta a necessidade de bem estar coletivo, mesmo que para isso seja necessário desestruturar comunidades e degradar o meio ambiente. Para tanto, é difundida a falácia de que os impactos socioambientais decorrentes dos grandes projetos de desenvolvimento no Amapá são infinitamente menores do que seus benefícios.

Diante destas premissas, o objetivo deste artigo é evidenciar as estratégias de introdução do projeto de desenvolvimento hegemônico no Amapá. Para tanto, a metodologia da pesquisa foi baseada na fundamentação em torno da lógica territorial do projeto de desenvolvimento hegemônico e seu sistema político-ideológico construído a partir de estratégias de consenso e coerção. Também foi utilizada como estratégia metodológica a coleta de dados primários por meio de entrevistas com os povos tradicionais atingidos pelos empreendimentos do grande capital no estado, a fim de qualificar a dinâmica de desenvolvimento hegemônico e evidenciar como são construídas as práticas coercitivas no Amapá. Foram coletados também informações publicadas na mídia sobre os empreendimentos do grande capital, a fim de entender o tratamento ideológico dado a eles, e dados sobre a violência no campo, oriundo da Comissão Pastoral da Terra, a fim de quantificar e espacializar a dinâmica coercitiva.

\section{A NOVA LÓGICA TERRITORIAL E SEU SISTEMA POLÍTICO-IDEOLÓ- GICO}

Desde a criação do Território Federal do Amapá, em 1943, houve a inauguração de uma política territorial de implantação de infraestrutura capaz de integrar o território aos circuitos produtivos da econômica nacional e global. De forma gradual foram construídas rodovias, uma ferrovia, uma usina hidrelétrica e redes de transmissão de energia, ao longo da segunda metade do século XX. Apesar do incremento da infraestrutura implantada no Amapá não houve a integração territorial efetiva capaz de permitir o franco desenvolvimento do capitalismo em suas terras, devido ao fato das rodovias não serem pavimentadas e a infraestrutura de transmissão de energia contemplar apenas a capital e o eixo urbano-industrial formado a partir da concessão de mineração de manganês da Icomi no município de Serra do Navio.

O Programa de Aceleração do Crescimento (PAC), criado em 2007, reativou os investimentos em infraestrutura no Amapá. Foi iniciada a pavimentação asfáltica de rodovias, a construção de novas usinas hidrelétricas, a implantação de linhas de transmissão do Sistema Interligado Nacional, a construção da Ponte Binacional entre o Amapá e a Guiana Francesa e a reestruturação da infraestrutura portuária e aeroportuária do Amapá. Estas obras de infraestrutura representaram a consolidação das redes técnicas necessárias à expansão territorial do capitalismo no Amapá, permitindo, principalmente, o desenvolvimento do agronegócio, da mineração, da indústria madeireira e da indústria pesqueira.

A territorialização do capital no Amapá representa os interesses do poder hegemônico no 
aproveitamento do potencial logístico-localizacional e dos bens naturais do Amapá para a reprodução do capital. Cabe analisar como esta premissa está inserida nos mecanismos estatais de manutenção da ordem hegemônica. Para tanto, inicialmente, destaca-se o fato de que o PPA 2016-2019 do Governo do Estado do Amapá é claro ao afirmar logo em seu primeiro parágrafo:

O Amapá, ao tornar-se unidade federativa, vem buscando traçar caminhos para o seu desenvolvimento, no entanto os desafios são muitos quando há um grande celeiro natural como à pesca, minério, madeira, frutas, produtos florestais, madeireiros e não madeireiros, que não se revertem como matéria-prima em prol de seu desenvolvimento, ou seja, é um Estado rico em sua biodiversidade, mas pobre em sua economia que representa $\mathrm{R} \$ 10,4$ bilhões, apenas $0,22 \%$ do PIB brasileiro (IBGE, 2014) (AMAPÁ, 2016).

A mensagem é simples e clara: o planejamento governamental visa a apropriação capitalista dos bens naturais do Amapá. Não há outra centralidade além da alimentação das estatísticas econômicas, que tem o Pib como principal indicador. Não é a inserção dos povos tradicionais com seu modo de vida, indiferente à reprodução do capital, que irá lograr o êxito econômico desejado pelo Estado. Apenas o grande capital possui o potencial necessário para garantir a elevação dos índices de desenvolvimento econômico e atender o sistema hegemônico, convertendo bens naturais em capital.

O que ocorre no Amapá é reflexo da introdução da lógica hegemônica global, em que são abandonadas as potencialidades da economia interna, de caráter regional e ligada ao modo de vida dos povos tradicionais, como a produção de alimentos, o extrativismo, a pesca artesanal, a manufatura artesanal, entre outros. Em substituição, adota-se uma economia completamente estranha ao território, conforme a demanda do mercado internacional, como o agronegócio sojicultor, a silvicultura de eucalipto, a mineração de manganês, entre outros elementos estranhos ao cotidiano da população e com pouca aplicação prática no mercado interno, pois o foco é a exportação. A este fenômeno, Milton Santos e Maria Laura Silveira denominam de especialização alienígena alienada (2006, p. 299). Trata-se da exigência do mercado global, que impõe uma nova racionalidade ao espaço e à economia local, desfrutando das vantagens comparativas que o espaço oferece, desestruturando antigas territorialidades e agregando, gradativamente, e com apoio e patrocínio do Estado, uma nova estrutura de produção especializada, conforme explica Milton Santos e Maria Laura Silveira:

Todas essas vantagens comparativas que exaltam os índices econômicos obtidos devem, pois, ser contrastadas com o fato de a coerência e, às vezes, o brilho das atividades locais constituírem uma coerência subordinada, dependente de entidades estranhas à área e cujo processo obedece a mandamentos que não têm nem inspiração local nem preocupação com os destinos locais (exceto naquilo que corresponde ao seu interesse privativista e imediato), de modo que o processo de crescimento realizado no lugar pode ser definido como um processo alienado, o que autoriza a considerar tais atividades como especializações não apenas alienígenas, por sua origem, mas alienadas, pelo seu desenvolvimento e destino. Nesse caso, não se trata apenas de uma exteriorização ou abertura - como parece da moda atualmente -, mas de verdadeira alienação. $\mathrm{Na}$ realidade, é de um conjunto de alienações que se trata, cada qual atraindo e alimentando a outra. (SANTOS e SILVEIRA, 2006. p. 300-301)

A especialização espacial exige também a estruturação de um conjunto de serviços agrega-

PRACS: Revista Eletrônica de Humanidades do Curso de Ciências Sociais da UNIFAP https://periodicos.unifap.br/index.php/pracs ISSN 1984-4352 Macapá, v. 13, n. 2, p. 253-270, jul./dez. 2020 
dos que possibilitam a plena reprodução da atividade. Desta forma, no Amapá, multiplicamse os empreendimentos de serviços relacionados ao agronegócio, a mineração, a indústria madeireira e a indústria pesqueira. Os novos negócios no setor de serviços atuam como forma complementar e de suporte aos circuitos produtivos e estão, geralmente, instalados nas zonas urbanas. Com isso, o discurso desenvolvimentista ganha materialidade nas cidades por meio dos serviços especializados. Gradualmente, toda a economia do Amapá passa a estabelecer fundamentos nos grandes projetos de desenvolvimento, gerando uma nova base socioespacial sistêmica, conforme descrito por Milton Santos e Maria Laura Silveira:

Cada atividade constitui, no conjunto, um processo para as demais, um elo importante no sistema produtivo criado em determinado lugar ou área, constituindo a base socioespacial sobre a qual assenta uma determinada equação de emprego, uma determinada massa salarial, um determinado ritmo das atividades, um determinado movimento dos agentes, dos produtos, das mercadorias, do dinheiro e da informação, uma determinada estrutura de ordens e um determinado sistema de poder fundado na economia e na política. Trata-se de um verdadeiro sistema coerente, cuja base é espacial. Assim, numa pequena área pode haver acúmulo de relações que se sustentam mutuamente e tendem à criação de um produto econômico importante se comparado com outras áreas do país, levando-se em conta a superfície ocupada e a população concernida. (SANTOS e SILVEIRA, 2006. p. 300)

Esta relação sistêmica constitui uma nova racionalidade socioespacial dos atores hegemônicos, descolada do modo de vida da população local. Como exemplo no Amapá temos a produção de farinha de mandioca e açaí, tradicionalmente utilizados na culinária regional, que perde espaço para a produção de soja e eucalipto, por exemplo. Trata-se da substituição de uma lógica local de produção, ligada à racionalidade dos povos tradicionais, por uma lógica exógena de produção, ligada à racionalidade do capitalismo global. Esse tipo de mudança leva a necessidade de o poder hegemônico tornar os elementos, que são estranhos à realidade local, em uma racionalidade sistêmica, fazendo crer que sem aquela nova lógica de produção não seria possível dar continuidade ao "desenvolvimento", que pretensamente é almejado pela população.

Da mesma forma, para subsidiar o processo de integração territorial competitiva do Amapá aos circuitos produtivos são tecidas estratégias político-ideológicas de controle e coerção social pelos atores hegemônicos, criando uma psicosfera positiva para a execução das grandes obras de infraestrutura e instalação dos empreendimentos do grande capital. A construção de usinas hidrelétricas, o desenvolvimento do agronegócio, a atividade de mineração, a indústria petrolífera, a indústria pesqueira e a indústria madeireira passam a figurar como elementos da modernidade, envolvidos em um discurso desenvolvimentista, que aparentemente figura como benéfico à população em geral, mas que mascara o fato de beneficiarem, na prática, apenas os atores hegemônicos, trazendo consigo inúmeros impactos sociais e ambientais.

No processo de apropriação dos bens naturais pelo grande capital no Amapá não só bens minerais, florestais, pesqueiros e territoriais são apropriados, mas também o componente humano aparece como recurso a reprodução do capital, como trabalhadores ou reserva de mão de obra, necessária ao controle salarial. Em reportagem publicada no portal de notícias G1, Juan Monteiro revela que o Amapá ganhou nove posições no ranking de competitividade dos estados brasileiros em 2015 e nos índices de crescimento do potencial da força de trabalho e taxa de crescimento o Amapá obteve uma das melhores colocações do País (MONTEIRO, 
2017). Este tratamento da mídia demonstra a forma como os povos do Amapá são vistos e apropriados como recurso potencial para o desenvolvimento do capitalismo. A disponibilidade de reserva de mão de obra no Amapá é um diferencial, ou uma vantagem comparativa, que expressa a potencialidade do desenvolvimento do capitalismo no discurso hegemônico. A competitividade territorial também se assenta no elemento humano, como instrumento de trabalho e reprodução do capital. Quanto maior o número de desempregados e menor a articulação sindical melhor será o potencial da força de trabalho para o grande capital, que poderá sujeitar o trabalhador a salários mais baixos, piores condições de trabalho e regimes menos rígidos de contratação.

Sustentando o discurso hegemônico, na intenção de criação de uma psicosfera positiva para a aceitação dos empreendimentos, está a retórica da geração de empregos, como dispositivo de garantia do bem estar social, por meio da absorção pelo mercado de trabalho destes mesmos povos, outrora impedidos de perpetuar seus modos de vida devido ao impacto dos empreendimentos. Entretanto, contrariando a ideia de geração de emprego, este potencial se revela positivo para o capitalismo justamente pela existência de uma grande massa de desempregados, gerando a possibilidade de mão de obra farta, barata e desarticulada. Em resumo, as condições para o desenvolvimento do capitalismo no Amapá são boas porque são péssimas as condições do trabalhador, se não fosse assim, não seria competitivo.

A estratégia de desenvolvimento traçada pelo Estado representa tão somente os interesses do poder hegemônico, por isso, precisa ser transfigurada como interesse público notório, para que possa transcorrer em sua plenitude dentro do contexto democrático brasileiro. Para tanto, o Estado tece estratégias de construção de uma psicosfera positiva em torno dos empreendimentos e atua com mecanismos de controle e coerção da sociedade para manter a ordem hegemônica. Esta dinâmica é reconhecida na dicotomia dos mecanismos de consenso e coerção concebidos por Antonio Gramsci na formulação do conceito de Estado ampliado (GRAMSCI, 2004, 2007). Neste conjunto, o consenso é estabelecido por meio das instituições e sua atuação no sentido de construir o reconhecimento e a aceitação das normas do poder hegemônico. Já a coerção se faz pelo estabelecimento de leis e os mecanismos para o seu cumprimento, como a inspeção, penalidades e violência.

O Estado é o representante, por excelência, do poder e o território nacional representa a conformação desse poder no espaço geográfico. Na ótica do Estado, a infraestrutura representa a forma de apropriação capitalista do território, provocando o desenvolvimento, ou, simplesmente, levando a "ordem e progresso". Tais afirmativas compõem o arcabouço retórico do poder hegemônico, como instrumentos de naturalização da racionalidade hegemônica, ou seja, naturalmente é necessário pensar que o caminho do desenvolvimento é o posto pelo Estado, em que apenas os interesses hegemônicos prevalecem. Esse instrumento, que se utiliza de argumentos desenvolvimentistas para a construção do consenso, ganha forma de opinião pública, ou seja, que é de notório conhecimento e alegação pela população em geral. Sobre este tema, Antonio Gramsci teceu um importante esclarecimento que merece ser citado:

O que se chama de "opinião pública” está estreitamente ligado à hegemonia política, ou seja, é o ponto de contato entre a "sociedade civil" e a "sociedade política", entre o consenso e a força. O Estado, quando quer iniciar uma ação pouco popular, cria preventivamente a opinião pública adequada, ou seja, organiza e centraliza certos elementos da sociedade civil. História da "opinião pública": naturalmente, elementos de opinião pública sempre existiram, mesmo nas satrapias asiáticas; mas a opinião pública como hoje se entende nasceu às vésperas da queda dos Estados

PRACS: Revista Eletrônica de Humanidades do Curso de Ciências Sociais da UNIFAP https://periodicos.unifap.br/index.php/pracs ISSN 1984-4352 Macapá, v. 13, n. 2, p. 253-270, jul./dez. 2020 
absolutistas, isto é, no período de luta da nova classe burguesa pela hegemonia política e pela conquista do poder.

A opinião pública é o conteúdo político da vontade política pública, que poderia ser discordante: por isso, existe luta pelo monopólio dos órgãos da opinião pública - jornais, partidos, Parlamento -, de modo que uma só força modele a opinião e, portanto, a vontade política nacional, desagregando os que discordam numa nuvem de poeira individual e inorgânica (GRAMSCI, 2007, p. 265).

A atualidade das reflexões de Antonio Gramsci pode ser interpretada a partir da leitura da relevância do papel da mídia, da política partidária e da atuação de governantes e parlamentares na contemporaneidade. Enquanto Antonio Gramsci já detectava estes elementos como decisivos para a constituição da opinião pública no inicio do século $\mathrm{XX}$, esta dinâmica não se alterou na contemporaneidade, pelo contrário, teve sua potencialidade agigantada pelo desenvolvimento das telecomunicações e a hegemonia da grande mídia.

Os atores hegemônicos engendram junto a grande mídia a falácia do desenvolvimento, que envolve, essencialmente, a atuação do Estado como gerador de oportunidades para todos. Por isso, os elementos simbólicos são referenciais da política estatal que pretensamente é feita em benefício de todos, mas é estruturalmente, sistematicamente e fundamentalmente produto dos interesses hegemônicos. Como exemplo, é possível verificar as propagandas do Governo do Estado do Amapá na mídia e junto das obras de infraestrutura, onde aparecem frases de alusão ao caráter social das políticas territoriais, conforme demonstrado na Fotografia 1:

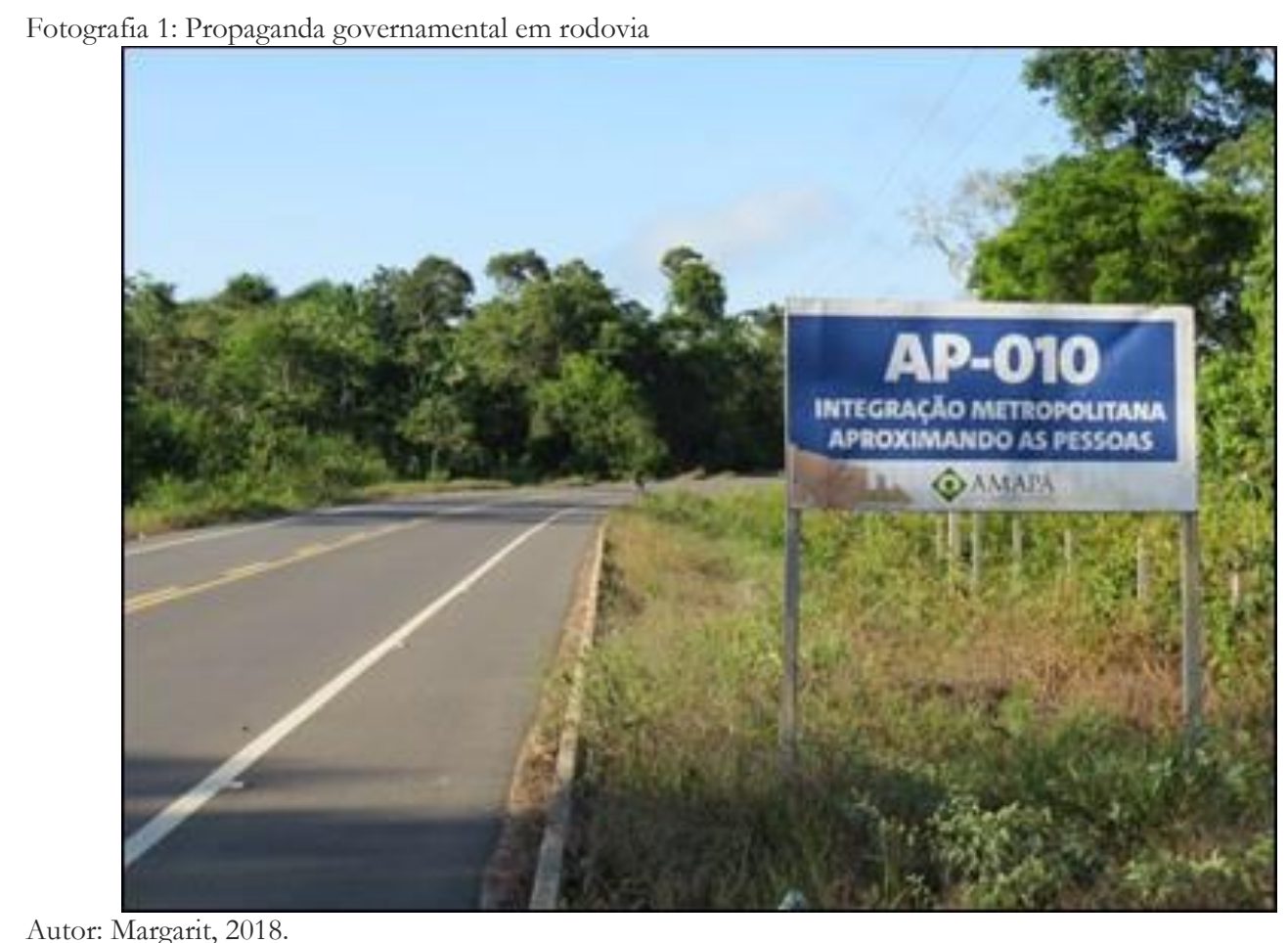

Este tipo de construção simbólica agrega a sociedade como um todo como beneficiada das grandes obras de infraestrutura. É inegável que diversas pessoas são beneficiadas por grandes obras, como a pavimentação asfáltica de rodovias. A circulação de pessoas entre as cidades e comunidades do interior e a capital é extremamente dependente das rodovias e sua pavimen- 
tação certamente beneficia quem precisa se deslocar pelas estradas. Entretanto, a questão central a ser analisada é que as obras de pavimentação só ocorrem por se tratar de interesse dos setores produtivos. Basta constatar que outras vias que não são de interesse destes setores acabam por não serem beneficiados com a mesma prioridade na execução de pavimentação asfáltica. Inúmeras são as comunidades que não possuem acesso rodoviário em boas condições de tráfego e até mesmo na periferia da zona urbana da capital muitas ruas ainda não são pavimentadas.

Em outra esfera de análise dos mecanismos do Estado de consenso está a questão do trabalho. Essencialmente o trabalho do Estado condiciona o trabalho da população, que precisa ser convencida por mecanismos consensuais de fazer parte do processo de desenvolvimento concebido pelo Estado. Afinal, o mecanismo propulsor da acumulação capitalista é o trabalho e sua superexploração. Por isso, a mensagem ao trabalhador é igualmente uma mensagem que busca agregar o caráter pessoal e social de sua condição ao caráter estatal de desenvolvimento, como demonstrado na Figura 1, extraída da página inicial na internet do Governo do Estado do Amapá.

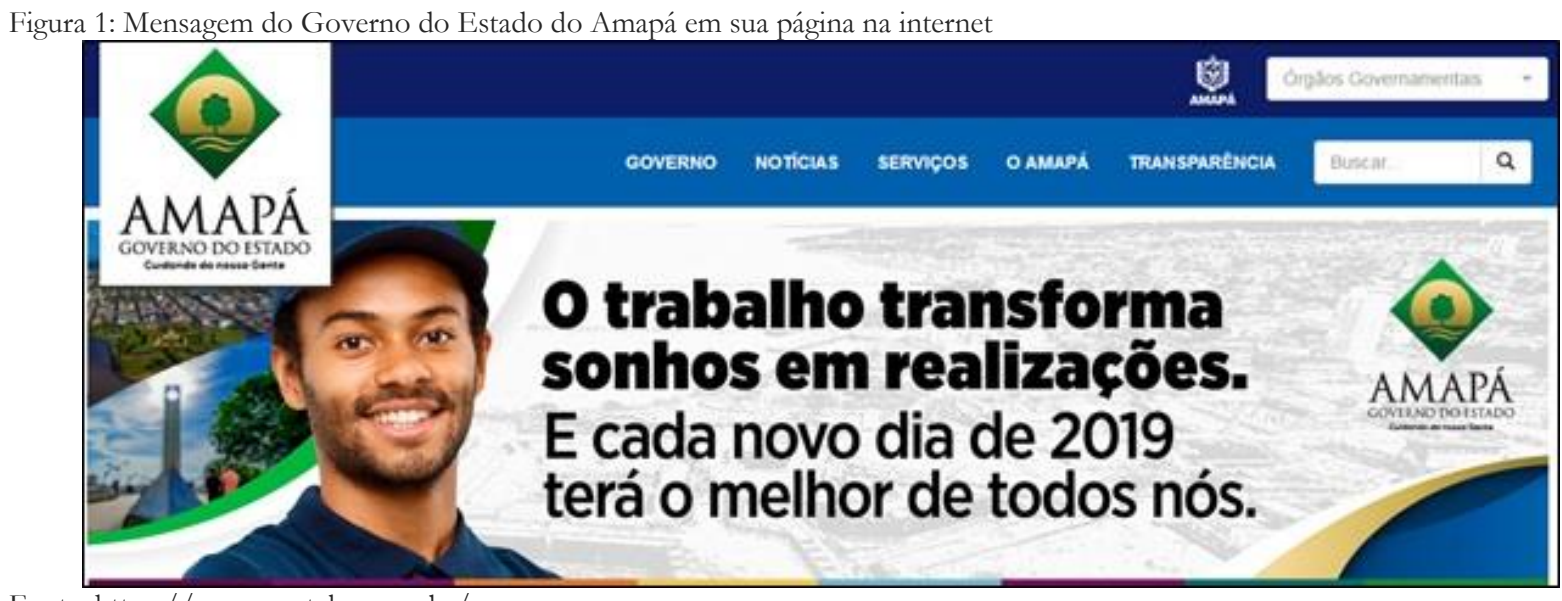

Fonte: https://www.portal.ap.gov.br/

São mecanismos simbólicos e sutis como estes que aproximam o ideal estatal do ideal da população, unindo-os na forma de opinião pública, que passa a considerar a geração de empregos o imperativo do papel do estado como condição de atendimento às demandas individuais da sociedade. No plano da coletividade o modelo se completa com a oferta de serviços públicos, especialmente, nas áreas de saúde e educação, modelados pelo capacidade de arrecadação do Estado, igualmente dimensionado pelos índices de desenvolvimento econômico.

Envolto nesta visão sistêmica, o aparato estatal trata de implantar o consenso sob a premissa de que só haverá desenvolvimento social se houver desenvolvimento econômico. Para tanto, os agentes estatais constroem esta retórica nos pronunciamentos e comunicados oficiais por meio desta estratégia ideológica. Para exemplificar esta dinâmica foram selecionadas notícias publicadas nas páginas da internet das instituições. A seleção foi feita por meio de ferramenta de busca no próprio site pelo termo "desenvolvimento". Devido ao volume de dados serão apresentados nos quadros a seguir apenas informações de 2015 em diante.

Inicialmente, o Quadro 1 traz o título das notícias publicadas no portal da internet do Governo do Estado do Amapá, entre 2015 e janeiro de 2019, que abordam a questão do desenvolvimento capitalista. Destaca-se os títulos vinculados ao desenvolvimento e a geração de 
empregos, politicas territoriais, empreendimentos capitalistas, infraestrutura, entre outros.

Quadro 1: Notícias sobre desenvolvimento publicadas pelo Governo do Estado do Amapá (2015-jan. 2019)

\begin{tabular}{|c|c|}
\hline Data & Título \\
\hline $15 / 10 / 2015$ & Projeto vai incentivar aumento da produção leiteira no Amapá durante a $51^{a}$ Expofeira \\
\hline $27 / 10 / 2015$ & GEA fortalece setor primário a partir da pavimentação da Rodovia AP-340 \\
\hline $30 / 10 / 2015$ & Com foco no desenvolvimento econômico, $51^{a}$ Expofeira abre as portas \\
\hline $03 / 11 / 2015$ & Expositores de máquinas apostam no faturamento com crescimento da Agricultura Comercial \\
\hline $05 / 11 / 2015$ & Empresa de moagem de trigo movimenta negócios na 51ª Expofeira do Amapá \\
\hline $06 / 11 / 2015$ & Investidores recebem autorização para implantação de novos empreendimentos no Amapá \\
\hline $03 / 12 / 2015$ & Amapá lança edital para transformar potencial madeireiro em desenvolvimento econômico \\
\hline $04 / 12 / 2015$ & Seminário discute desenvolvimento econômico e social da Amazônia Legal \\
\hline $26 / 02 / 2016$ & Indústria de tintas busca apoio da Agência de Desenvolvimento Econômico do Amapá \\
\hline $12 / 05 / 2016$ & Regularização de terras vai oportunizar novos investimentos no Amapá \\
\hline $15 / 05 / 2016$ & Empresas do Amapá podem ser as primeiras beneficiadas pela ZFV \\
\hline $18 / 05 / 2016$ & Waldez Góes apresenta potenciais econômicos para atrair investimentos ao Amapá \\
\hline $30 / 05 / 2016$ & Amapá e Guiana Francesa discutem novas rotas de exportação \\
\hline $14 / 06 / 2016$ & Safra de grãos em 2016 será 56,34\% maior que em 2015 \\
\hline $24 / 06 / 2016$ & Logística usada por petrolífera gera expectativas na economia do Amapá \\
\hline $20 / 07 / 2016$ & Governador Waldez Góes lidera comitiva amapaense em busca de investimentos para o Amapá \\
\hline $22 / 07 / 2016$ & Rodovia AP-010 é entregue oficialmente à população de Mazagão \\
\hline $27 / 07 / 2016$ & Amapá dá primeiro passo para exportação de soja \\
\hline $11 / 08 / 2016$ & Amapá inicia ciclo industrial com entrega de títulos e declarações de reservas de área \\
\hline $08 / 09 / 2016$ & Exportação de Soja aumentará postos de empregos no Amapá \\
\hline $09 / 09 / 2016$ & Governo do Estado firma parceria com investidores da China \\
\hline $11 / 11 / 2016$ & Reunião define projeto de utilização do Distrito Industrial \\
\hline $23 / 11 / 2016$ & Governo e Basa firmam parceria de acesso ao crédito para empresas da Zona Franca Verde \\
\hline $02 / 12 / 2016$ & Governo do Amapá apresenta projetos de investimentos a empresários chineses \\
\hline $07 / 12 / 2016$ & Ponte vai possibilitar transporte de matéria prima para indústrias da Zona Franca Verde \\
\hline $10 / 12 / 2016$ & Projetos de desenvolvimento econômico entre Amapá e Guiana serão ampliados em 2017 \\
\hline $12 / 12 / 2016$ & GEA entrega Ponte da Integração e reforça política de desenvolvimento econômico \\
\hline $12 / 12 / 2016$ & Governo destaca benefícios em setores da economia após entrega da Ponte da Integração \\
\hline $14 / 12 / 2016$ & Governo dialoga com grupos árabes para atrair investimentos ao Amapá \\
\hline $15 / 12 / 2016$ & Fábrica de cimento pode baratear preço e impulsionar a construção civil no Estado \\
\hline $16 / 12 / 2016$ & Governo do Amapá apresenta vocações produtivas para investidores árabes \\
\hline $06 / 01 / 2017$ & Governo reafirma compromisso com desenvolvimento de Mazagão \\
\hline $20 / 02 / 2017$ & Plano Conjunto contribuirá para o desenvolvimento econômico dos municípios \\
\hline $24 / 04 / 2017$ & Governo apoia a entrada da Amcel no mercado de grãos \\
\hline $28 / 04 / 2017$ & Afap comemora 17 anos dedicados ao desenvolvimento econômico do Amapá \\
\hline $11 / 05 / 2017$ & Início da industrialização na Zona Franca Verde vai gerar quase 400 empregos \\
\hline $17 / 05 / 2017$ & Ponte Binacional estimula alternativas de desenvolvimento econômico na fronteira \\
\hline $26 / 05 / 2017$ & Selo vai levar o nome do Amapá aos mercados nacional e internacional \\
\hline $29 / 05 / 2017$ & Grupo poderá facilitar acesso ao crédito e acelerar desenvolvimento econômico do Amapá \\
\hline $12 / 06 / 2017$ & Amapá busca alternativas para fortalecer a agroindústria local \\
\hline $25 / 07 / 2017$ & Câmara Setorial discute expansão da produção de grãos no Amapá \\
\hline $27 / 09 / 2017$ & Estudo de cabotagem apresenta novos caminhos para o desenvolvimento econômico no Amapá \\
\hline $01 / 11 / 2017$ & Governo e mineradora discutem expansão na exploração de ouro no Amapá \\
\hline $12 / 12 / 2017$ & Incentivos fiscais e políticas econômicas do Amapá atraem companhia multinacional \\
\hline $15 / 12 / 2017$ & Conselho de Administração da Suframa aprova US\$ 339,6 mi em investimentos na Amazônia \\
\hline $17 / 01 / 2018$ & Projeto de concessão florestal vai abrir 200 postos de trabalho no Amapá \\
\hline $27 / 06 / 2018$ & Empresa de energia solar inicia processo para se instalar no Distrito Industrial do Amapá \\
\hline $28 / 11 / 2018$ & Empresários sul-coreanos querem investir no Amapá \\
\hline $06 / 12 / 2018$ & Empresa de mineração expande atividades no Amapá com apoio do Estado \\
\hline $07 / 12 / 2018$ & Potencialidades do Amapá atraem embaixador de Luxemburgo no Brasil \\
\hline $10 / 12 / 2018$ & Waldez Góes acerta destinação de R \$ 450 milhões do FNO para o Amapá, em 2019 \\
\hline $01 / 01 / 2019$ & Durante posse, governador afirma que vai priorizar desenvolvimento econômico do Amapá \\
\hline $11 / 01 / 2019$ & Governo avalia criação de um Centro de Desenvolvimento Econômico do Amapá \\
\hline $17 / 01 / 2019$ & Amapá e Pará buscam soluções conjuntas para desenvolverem vocações produtivas \\
\hline $30 / 01 / 2019$ & Amapá e Banco da Amazônia assinam protocolo de investimentos de mais de $\mathrm{R} \$ 400$ milhões \\
\hline $31 / 01 / 2019$ & Eficiência do Amapá atrai R\$ 450 mi do FNO para o setor produtivo \\
\hline
\end{tabular}

Fonte: https://www.portal.ap.gov.br/noticias

Organização e elaboração: Margarit, 2019.

PRACS: Revista Eletrônica de Humanidades do Curso de Ciências Sociais da UNIFAP https://periodicos.unifap.br/index.php/pracs ISSN 1984-4352 Macapá, v. 13, n. 2, p. 253-270, jul./dez. 2020 
A atuação parlamentar é outro sustentáculo fundamental do consenso entorno da política de desenvolvimento hegemônico. A Assembleia Legislativa do Amapá é palco de defesa constante dos interesses hegemônicos e seus parlamentares trabalham na consolidação desses interesses. O Quadro 2 cita o título das notícias sobre a atuação dos parlamentares da Assembleia Legislativa do Amapá, entre 2015 e 2018, que sugerem a defesa do projeto de desenvolvimento hegemônico, apontando para as alianças políticas do grande capital.

Quadro 2: Notícias sobre a atuação dos parlamentares da Assembleia Legislativa do Amapá em questões relativas ao desenvolvimento (2015-2018)

\begin{tabular}{|c|c|}
\hline Data & Título \\
\hline $29 / 07 / 2015$ & Deputado Max articula reunião do Banco do Brasil com governador para fortalecer agronegócio no Amapá \\
\hline $25 / 08 / 2015$ & Cônsul do Japão faz visita ā Assembleia Legislativa e fala de investimentos no Amapá \\
\hline $08 / 09 / 2016$ & Assembleia Legislativa participa de evento histórico no Porto de Santana \\
\hline $08 / 09 / 2016$ & Deputada Edna Auzier destaca embarque de grãos e evoluião do Amapá como Estado Produtor \\
\hline $06 / 10 / 2016$ & Deputado Augusto Aguiar defende abertura do capital do Porto de Santana \\
\hline $20 / 10 / 2016$ & Deputado Max pede celeridade na conclusão do porto de embarque de minérios em Santana \\
\hline $14 / 12 / 2016$ & Deputados participam de almoço e palestra sobre a Ponte da Integração \\
\hline $17 / 12 / 2016$ & Luciana Gurgel propõe a "Semana de Apoio ao Emprego e Geração de trabalho \\
\hline $01 / 02 / 2017$ & Deputada Marilia Góes recebe empresários para discutir melhorias para o setor do comércio no Amapá \\
\hline $16 / 05 / 2017$ & Deputados destacam a importância da reunião do Conselho de Administração da Suframa no Amapá \\
\hline $05 / 06 / 2017$ & COF e CJR debatem com classes empresariais, projeto referente à Zona Franca Verde \\
\hline $23 / 06 / 2017$ & Luciana Gurgel vai ao Ministério dos Transportes solicitar a retomada da obra da BR-156 \\
\hline $02 / 08 / 2017$ & CJR e COF aprovam Projeto de Lei que pode alavancar a economia do Estado \\
\hline $03 / 08 / 2017$ & Plenário da Assembleia Legislativa aprova Projeto de Lei que cria incentivos fiscais ao setor industrial do Estado \\
\hline $17 / 10 / 2017$ & Alap participa de debate sobre Projeto de Lei que visa ligar o Amapá ao Pará e a Roraima por meio da BR-156 \\
\hline $25 / 10 / 2017$ & Comissão de Empreendedorismo busca parcerias para qualificar população do Amapá \\
\hline $31 / 10 / 2017$ & Membros da Comissão de Transportes e Obras da Alap participam de capacitação sobre engenharia de tráfego \\
\hline $10 / 11 / 2017$ & Deputados conhecem trabalho de mineradora que atua no Pará e levam experiência ao setor mineral do Amapá \\
\hline $21 / 11 / 2017$ & Comissões da Alap visitarão usinas hidrelétricas de Ferreira Gomes e órgãos públicos de Oiapoque \\
\hline $21 / 02 / 2018$ & DaLua aposta no desenvolvimento econômico do estado após pavimentação do trecho sul da BR-156 \\
\hline $07 / 03 / 2018$ & Comissões da Assembleia Legislativa visitarão distrito do Lourenço \\
\hline $13 / 03 / 2018$ & Assembleia Legislativa do Amapá participará do lançamento da $7^{a}$ edição do Anuário Mineral \\
\hline $11 / 04 / 2018$ & Comissões da Alap buscarão subsídios no interior do Pará para alavancar setor mineral no Amapá \\
\hline $12 / 04 / 2018$ & Parlamentares saem otimistas de explanação sobre crescimento do setor mineral no Pará \\
\hline $14 / 04 / 2018$ & Comissões solicitam reinstalação de escritório da Companhia de Pesquisa de Recursos Minerais no AP \\
\hline $16 / 04 / 2018$ & Mineração: deputados dão encaminhamentos aos trabalhos desenvolvidos em Belém \\
\hline $16 / 04 / 2018$ & Potencialidades do Amapá no setor mineral serão apresentadas à população do estado \\
\hline $18 / 04 / 2018$ & No Dnit, presidente Kaká Barbosa pede urgência nas obras do trecho sul da BR-156 \\
\hline $30 / 05 / 2018$ & Audiência pública busca reverter situação de desemprego dos garimpeiros de Tartarugalzinho \\
\hline $31 / 05 / 2018$ & CAP discutirá desenvolvimento econômico no município de Oiapoque \\
\hline $15 / 06 / 2018$ & Deputada Luciana Gurgel participa de assinatura da ordem de serviço de pavimentação da BR-156 \\
\hline $20 / 06 / 2018$ & Comissões alinham atividades com finalidade de potencializar setor mineral do Amapá \\
\hline $21 / 06 / 2018$ & $\begin{array}{l}\text { Na Alepa, deputados amapaenses pedem apoio no fortalecimento do setor mineral do AP e pretendem criar Frente } \\
\text { Parlamentar }\end{array}$ \\
\hline $22 / 06 / 2018$ & Cadastro de Recursos Minerários do Pará é apresentado para comissões da Alap \\
\hline $25 / 06 / 2018$ & Mineração: deputados propõem ao Serviço Geológico do Brasil instalação de um polo da CPRM no Amapá \\
\hline $29 / 06 / 2018$ & $\begin{array}{l}\text { Presidente da Comissão de Empreendedorismo, deputada Luciana Gurgel participa de visita técnica à obra do novo } \\
\text { aeroporto }\end{array}$ \\
\hline $08 / 08 / 2018$ & Tribuna: Cristina fala da crise do setor madeireiro de Pedra Branca do Amapari \\
\hline $19 / 11 / 2018$ & Deputados buscam elementos que possam ajudar setor mineral do Amapá a sair do entrave \\
\hline $22 / 11 / 2018$ & Plano de Mineração do Pará é apresentado aos membros das comissões de Indústria e de Administração da Alap \\
\hline $22 / 11 / 2018$ & Agência Nacional de Mineração aponta caminhos para fortalecimento do setor mineral \\
\hline
\end{tabular}
Fonte: http://www.al.ap.gov.br/pagina.php?.pg=buscar_noticia

Organização e elaboração: Margarit, 2019.

A grande mídia também tem sido um instrumento essencial de propagação desses mesmos valores ambíguos, que exaltam os empreendimentos do grande capital por meio da divulgação de seu processo de expansão e trunfos. A TV Amapá, afiliada da Rede Globo, possuí uma 
programação local que é a mais assistida pela população e tem servido como principal ancora de construção consensual do projeto hegemônico de desenvolvimento. No Quadro 3, a seguir, foram transcritos os títulos das reportagens veiculadas por este canal sobre os grandes projetos de desenvolvimento, entre 2015 e 2018.

Quadro 3: Reportagens da TV Amapá sobre os grandes projetos de desenvolvimento (2015 e 2018)

\begin{tabular}{|c|c|}
\hline Data & Título \\
\hline $13 / 01 / 2015$ & Hidrelétrica Coaracy Nunes completa 39 anos de operação comercial no Amapá \\
\hline $14 / 01 / 2015$ & Amapá será ligada ao sistema brasileiro de energia elétrica \\
\hline $01 / 06 / 2015$ & Amapá se prepara para escoar soja pelo Porto de Santana \\
\hline $16 / 06 / 2015$ & Em 2015, Amapá deve produzir mais de 45 mil toneladas de soja \\
\hline $28 / 07 / 2015$ & No Amapá, pelo menos 26 mil toneladas de soja deverão ser produzidas este ano \\
\hline $01 / 09 / 2015$ & Fundação de Pesquisa conclui estudos preliminares sobre exploração de petróleo \\
\hline $12 / 09 / 2015$ & CEA vai fazer interligação total do Amapá ao sistema nacional de energia \\
\hline $02 / 11 / 2015$ & Novos negócios no setor agropecuário ganham espaços na $51^{a}$ Expofeira do Amapá \\
\hline $20 / 11 / 2015$ & Encontro em Macapá discute o Plano Agropecuário do Amapá \\
\hline $21 / 01 / 2016$ & Zona Franca Verde no Amapá é pauta em reunião entre órgãos da economia em Manaus \\
\hline $21 / 01 / 2016$ & Inauguração da Ponte Binacional poderá aumentar a economia de Oiapoque \\
\hline $05 / 02 / 2016$ & Órgãos públicos discutem a criação de um distrito industrial próximo à Mazagão \\
\hline $12 / 02 / 2016$ & Zona Franca Verde de Macapá e Santana deve ser efetivada em alguns dias \\
\hline $13 / 02 / 2016$ & Obras do Aeroporto Internacional de Macapá podem ser concluídas em 2017 \\
\hline $19 / 02 / 2016$ & Empresas apresentam propostas para explorar a Floresta Estadual do Amapá \\
\hline $04 / 03 / 2016$ & No AP, ministro do desenvolvimento discute a implantação da Zona Franca Verde \\
\hline $20 / 06 / 2016$ & No Amapá, colheita de soja e feijão vai ser 50\% maior em 2016 \\
\hline $28 / 06 / 2016$ & Presidente da Aprosoja fala sobre aumento da produção de grãos no Amapá \\
\hline $30 / 06 / 2016$ & Está previsto para 2017 a perfuração de poços de petróleo no Amapá \\
\hline $28 / 07 / 2016$ & Soja plantada no Amapá este ano começou a ser colhida \\
\hline $09 / 09 / 2016$ & Amapá fez a primeira exportação de soja para o mercado europeu \\
\hline $10 / 09 / 2016$ & Personalidades amapaenses foram reconhecidas por darem desenvolvimento ao estado \\
\hline $07 / 10 / 2016$ & Programa 'Jovem Aprendiz Industrial' ajuda jovens do AP a entrarem no mercado de trabalho \\
\hline $22 / 10 / 2016$ & Exposição em Oiapoque mostra como vai ser a exploração de petróleo na costa do Amapá \\
\hline $02 / 03 / 2017$ & No Amapá, barragens hidrelétricas ajudam a prevenir enchentes no interior do estado \\
\hline $18 / 03 / 2017$ & Ponte binacional entre Brasil e Guiana Francesa é inaugurada neste sábado (18) \\
\hline $27 / 04 / 2017$ & No AP, encontro da Suframa vai discutir desenvolvimento industrial e comércio na Amazônia \\
\hline $09 / 05 / 2017$ & Indústrias de sorvete e ração do terão isenção de IPI no Amapá \\
\hline $11 / 05 / 2017$ & Cultura exportadora e indústria será discutida em reunião da Suframa em Macapá \\
\hline $26 / 06 / 2017$ & Desenvolvimento econômico sustentável e o agronegócio será discutido em Macapá \\
\hline $13 / 07 / 2017$ & Colheita de grãos aumenta mais de $10 \%$ em um mês no Amapá \\
\hline $20 / 09 / 2017$ & Agronegócio deve puxar elevação de $1,2 \%$ no PIB do Amapá em 2017, diz estudo \\
\hline $13 / 11 / 2017$ & Amapá cresce produção e tem o $2^{\circ}$ maior rebanho de búfalos do Brasil \\
\hline $22 / 11 / 2017$ & Amapá registra crescimento na produção de soja em 2017 \\
\hline $16 / 01 / 2018$ & Amapá vai exportar grãos para a Europa pela $1^{a}$ vez \\
\hline $31 / 01 / 2018$ & No AP, 20 empresas devem receber os benefícios da Zona Franca Verde \\
\hline $01 / 02 / 2018$ & Pescadores do município de Ferreira Gomes devem trabalhar na criação de peixes \\
\hline $17 / 02 / 2018$ & Soja continua liderando a produção agricula do Amapá, segundo o IBGE \\
\hline $05 / 04 / 2018$ & Amapá livre de febre aftosa atrai investimentos de produtores de 'olho' na exportação \\
\hline $31 / 05 / 2018$ & $1^{a}$ Expobúfalo no Amapá mostra as potencialidades da criação bubalina no estado \\
\hline $19 / 07 / 2018$ & IBGE continua estimando o aumento na produção de Soja no Amapá \\
\hline $25 / 10 / 2018$ & Governo Federal inclui aeroporto de Macapá em projeto que prevê acelerar obras no país \\
\hline
\end{tabular}

Fonte: http://g1.globo.com/ap/amapa/amapa-tv/videos/

Organização e elaboração: Margarit, 2019.

Como é possível observar, há uma ampla cobertura e a criação de uma relação otimista e consensual em torno dos projetos do grande capital, com destaque para o agronegócio, criando uma psicosfera positiva em torno deles. Como resultado, é possível verificar também a reprodução dessas ideias no imaginário popular, como opinião pública. A construção destes discursos tem se dado por meio da naturalização do desenvolvimento do capitalismo, criando a imagem de que há uma "vocação natural" do Amapá para determinadas atividades. Assim, 
o plantio de grãos no Cerrado Amapaense, por exemplo, é qualificado por meio das características edafoclimáticas deste bioma, minimizando questões ambientais e sociais, com total apoio da mídia, subsidiando, portanto, as condições ideológicas para o desenvolvimento do agronegócio no Amapá.

A indústria pesqueira também é cercada de discursos que hipervalorizam a "disponibilidade de recursos pesqueiros" devido à extensa costa marítima e rede hidrográfica que o Amapá possui, e, portanto, com potencial a ser explorado. $O$ mesmo se repete em relação à mineração, cuja simples disponibilidade de bens minerais no Amapá se torna argumento do discurso de propagação da necessidade de explorar a "riqueza" do subsolo. O discurso em torno da indústria madeireira segue a mesma vertente da retórica de exploração das riquezas, geração de empregos e desenvolvimento. Por fim, e dos mais recentes, é a construção do discurso em torno da atividade petrolífera, que envolve a comparação com outras unidades da federação que se desenvolveram pretensamente com a exploração deste bem. Em suma, todas as atividades do grande capital são apresentadas como meios fundamentais para o desenvolvimento do Amapá e a aproximação de seus benefícios à população é feita com a inclusão da ideia de geração de emprego e renda no discurso.

\section{O IMPÉRIO DA VIOLÊNCIA}

Quando o mecanismo consensual não é suficiente para manter a ordem hegemônica, a coerção passa a ser o instrumento de controle social. Este mecanismo é representado no Brasil pelos instrumentos legais e ilegais de manutenção da ordem hegemônica, em que as leis, instituições, governantes, forças armadas e atores locais se articulam na prática coercitiva. Não raro a violência faz parte desse mecanismo e vem sendo recorrente artifício contra os povos tradicionais da Amazônia.

No Amapá, a dinâmica coercitiva se realiza sob as mesmas bases, ou seja, as leis, as instituições, os governantes, as forças armadas e os atores locais agem coercitivamente contra a população para garantir os interesses do poder hegemônico. Neste contexto, a violência é instrumento recorrente. Mas é necessário destacar que a violência ocorre tanto de forma categórica, como simbólica.

A empresa Amapá Florestal e Celulose (Amcel) tornou-se o principal símbolo da propriedade privada e do latifúndio corporativo no Amapá, introduzindo a nova lógica de conceber a terra como instrumento de negócio. Na manutenção do poder sobre as terras a Amcel utilizase de instrumentos coercitivos para inibir a presença dos povos tradicionais que costumam a acessar as matas e cursos d'água de suas propriedades para perpetuar os hábitos de caça, pesca e extrativismo. Os instrumentos simbólicos de coerção da Amcel podem ser verificados na presença de placas e cercas (Fotografia 2 e Fotografia 3) e na própria magnitude dos extensos plantios, que, por si só, servem de instrumento de afirmação do poder da corporação nas terras sob seu domínio. A Amcel mantém ainda intenso controle sobre suas terras por meio de vigilantes que realizam rondas em motocicletas ${ }^{2}$. 


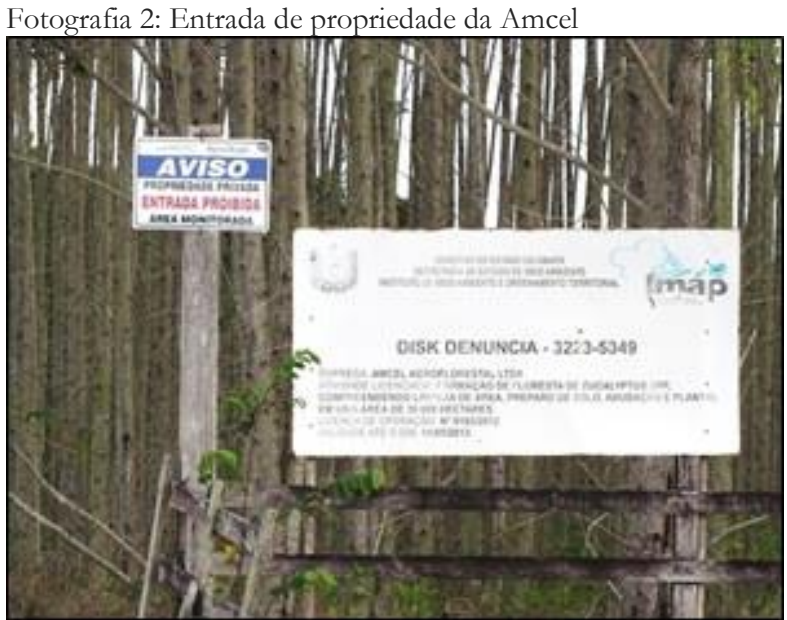

Autor: Margarit, 2017.

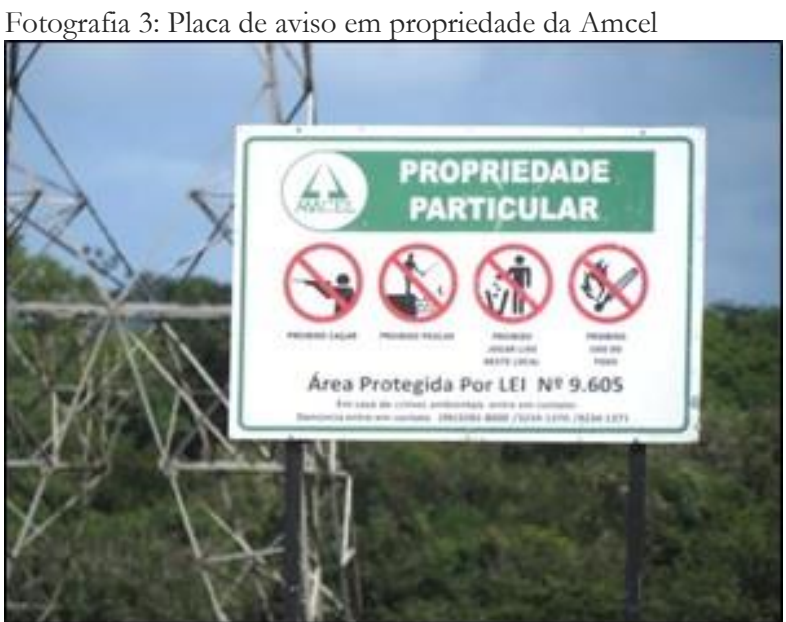

Autor: Margarit, 2017.

A construção das hidrelétricas no Amapá segue o mesmo caminho de afirmação da propriedade privada e mecanismos de coerção contra os povos tradicionais. O entorno das hidrelétricas e de seus lagos também se tornaram patrimônio do empreendimento, privatizando parte do rio e terras no entorno, que passaram a ter a entrada e atividades de caça e pesca proibidas. Este novo cenário de privatização do rio é cercado de elementos coercitivos, com vigilância do empreendimento e placas de sinalização, conforme exemplo retratado na Fotografia 4.

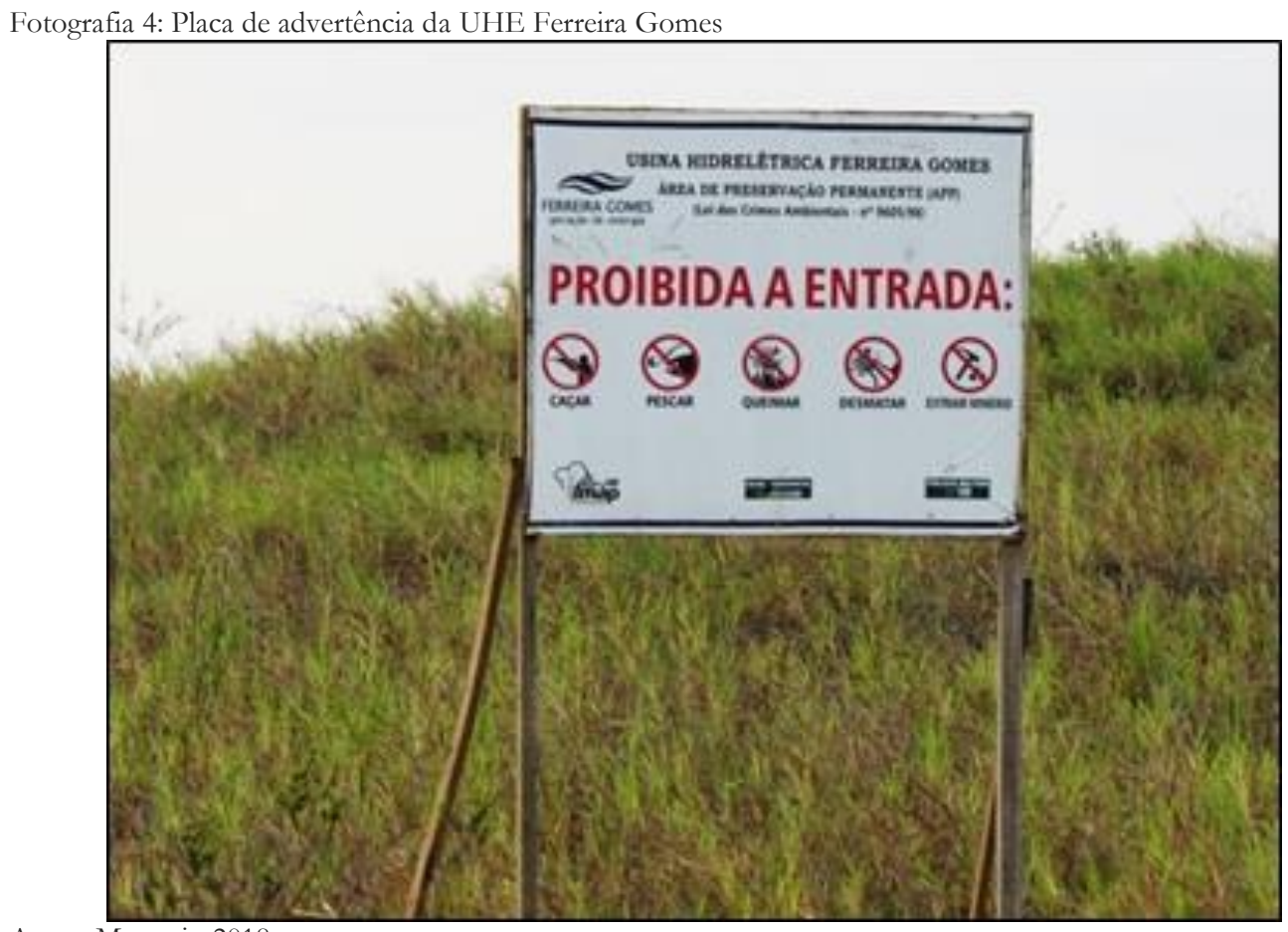

Autor: Margarit, 2018.

Com a introdução do agronegócio sojicultor no Amapá a questão fundiária se agravou ainda mais. Se antes os conflitos envolviam basicamente a Amcel, agora uma diversidade de atores passou a operar na apropriação capitalista das terras. A principal consequência da apropriação das terras do Amapá pelo grande capital é a mudança na forma de uso e ocupação das terras. Há um processo de criação de uma afirmação da propriedade privada, por meio de cercas e 
placas por toda a parte, algo que até então não era comum. A introdução dessa relação com a propriedade privada da terra, na qual os limites são bem definidos e defendidos, causa conflitos com os povos tradicionais do Amapá, por impedir a perpetuação de seus modos de vida, como relata o representante da comunidade de Santo Antônio da Pedreira, no município de Macapá:

É só assim: é não querer deixar entrar mais pra ir tirar açaí, pra ir mariscar, porque, é pegar a sua comida, tá entendendo? É assim. Porque quando nós se criamos aqui agente já pegava a comida da gente nessa mata aí, nesse mato grande, que agente chama. Então agente tá acostumado a ir buscar lá a alimentação da gente. Açaí, a comida, caça, peixe, entendeu? Era assim. E hoje agente tá passando essa necessidade porque agente já não pode entrar (A. C. S., 2018).

A aquisição de terras no Amapá por produtores de grãos de outros estados ignora o hábito de caça, pesca e extrativismo vegetal dos povos tradicionais, reprimindo com violência essas práticas, conforme relato de uma agricultora no Projeto de Assentamento Piquiá, no município de Amapá: "o pessoal do Amapá deixa os outros entrar pra tirar açaí, caçar, pescar. Esses de fora não. Entrou morreu” (A. O. C., 2017). Esta afirmação revela a clara diferença na relação com a propriedade da terra e seu controle entre o povo amapaense e o produtor de grãos proveniente de outros estados. Os "de fora" são em geral provenientes do Centro-Sul e trazem consigo uma outra forma de compreender a defesa da propriedade privada e temem a invasão nos moldes das que ocorrem por movimentos sociais em outros estados, dinâmica ainda não presente no Amapá, e, portanto, sem sentido para o povo amapaense.

A imperiosa necessidade de defesa dos limites da propriedade privada proporciona o cerceamento dos povos tradicionais do acesso aos bens naturais, mesmo que estes não venham a ser explorados por seu proprietário. Esta dinâmica, mesmo sendo legal, não é entendida como coerente e justa pelos povos tradicionais do Amapá, que em geral ignoravam esta lógica. Portanto, instalou-se nas terras do Amapá uma psicosfera de tensão e medo. A coerção passou a ser o instrumento básico de controle patrimonial. Multiplicaram-se as cercas e placas indicativas de propriedade privada. A Fotografia 5 apresenta uma das muitas placas desta natureza, junto a cercas de imóveis rurais, em diversos municípios do Amapá. É importante destacar que muitas destas trazem, inclusive, a indicação das proibições: “caça, pesca e extração de açaî", denotando a característica do conflito pelos bens naturais e não pela terra em si. 


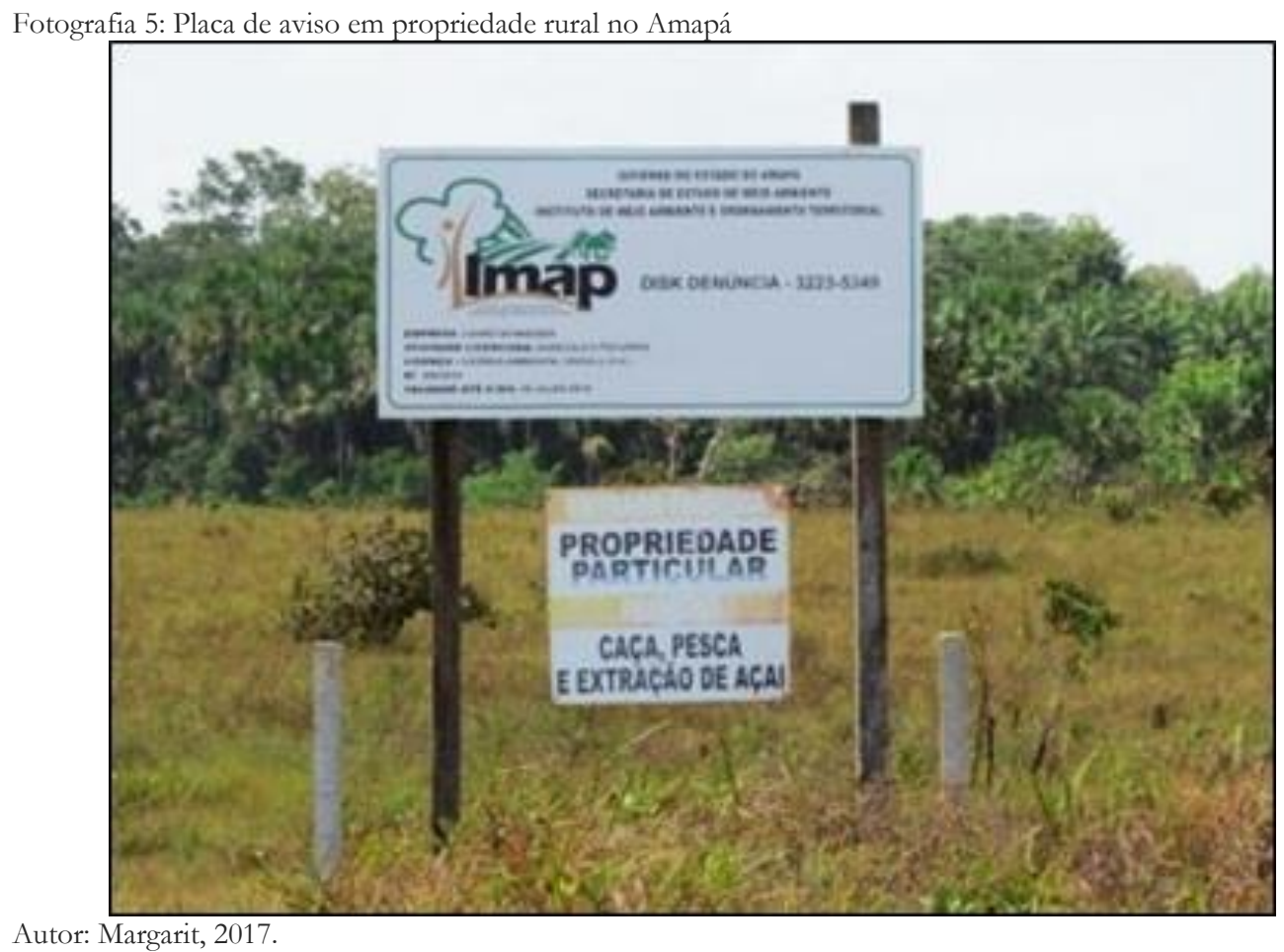

O processo de afirmação da propriedade privada da terra no Amapá ocorre em ritmo acelerado. Tal prerrogativa contrasta com a ineficiência dos órgãos públicos em reconhecer a territorialidade dos povos tradicionais e conceder licenças aos mesmos, conforme alerta uma agricultora expulsa da sua terra no município de Macapá:

Que esses pessoal aí parece que eles... tem um poder tão grande, né. Que, eu acho que eu tenho pra mim, assim, que deve ter com o governo do estado, né. Porque, uma pessoa dessas lá eles vem de lá pra cá, aí eles chega aqui parece que já tá tudo resolvido. Do dia pro outro eles chegam numa área dessa aqui desmatando tudo, tirando tudo. E placa dali, placa daqui, como vocês estão vendo, olha! Placa de tudo quanto é jeito aí. Aí eles no outro dia já tem licença. Aí a gente que mora aqui, né, após a anos, quando agente vai num órgão desses pra tirar uma licença pra... trabalhar, que agente quer trabalhar na verdade, né, aí agente fica, e vai pra ali, e vem pra cá, e volta, e nada dá certo. Aí agente fica todo esses ano dependendo. Agente não é bem atendido. Aí esse pessoal que chega, DO DIA PRO OUTRO, já tá bem atendido e tem tudo na mão pra eles. E agente daqui, filho daqui da terra, custa pra... entendeu, pra eles atender agente. Quando eles vem de lá pra cá, chega aqui, é duma hora pra outra. Tudo de segunda. É rápido demais. Até a soja deles são tão rápido também, que é rápido, que eles colocam tudo quanto é tipo de veneno aí, é tudo quanto é coisa, é um, dois também pra eles colherem aí. É rápido demais também (M. S. S. S., 2018).

A instituição da propriedade privada e o controle de seus limites não se dão sem violência. Os relatos dos povos tradicionais no Amapá atestam recorrentes casos de ameaça de morte a qualquer tentativa de invasão de propriedade, mesmo daqueles que ingenuamente entrariam apenas para extrair açaí, caçar ou pescar, práticas que ignoram limites de propriedades, de acordo com o modo de vida do povo amapaense e sua relação com a terra.

Os dados da CPT contribuem para revelar a proporção e a distribuição geográfica da vio- 
lência no campo no Amapá, além de sua relação com as grandes obras de infraestrutura. O Mapa 1 apresenta os conflitos no campo no Amapá acumulados desde o início do trabalho de levantamento da CPT, em 1985. Nele é possível notar que há um acumulo de conflitos em maior número nos municípios em que as redes técnicas são mais desenvolvidas e o grande capital se instalou, com destaque para Macapá, Porto Grande, Ferreira Gomes e Tartarugalzinho.

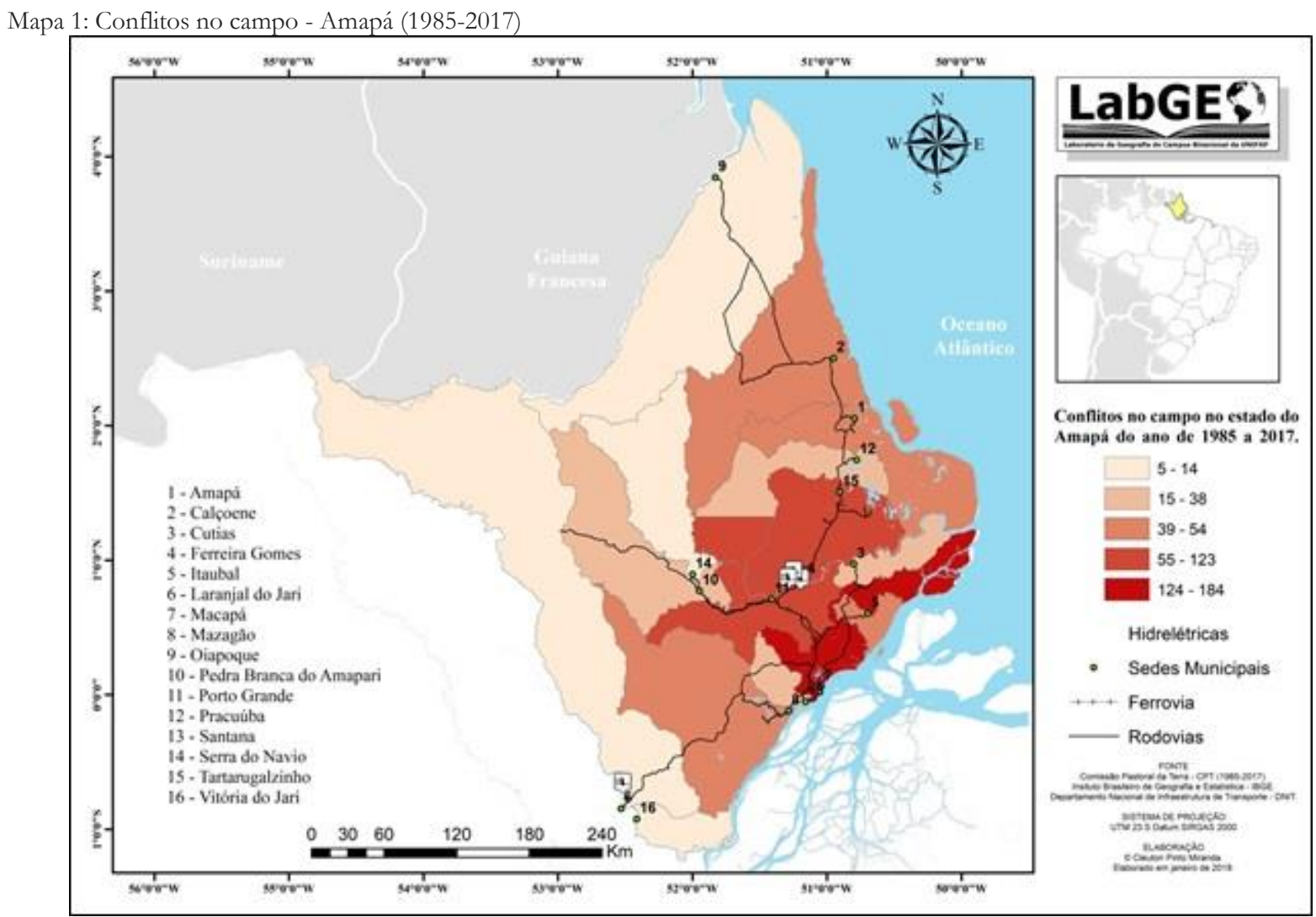

Quanto à temporalidade dos conflitos no campo no Amapá, ao analisar os dados que a CPT produz desde 1985, é possível deduzir que enquanto outros estados experimentavam o desgosto de sangrentos conflitos pela posse e uso da terra, no Amapá, os dados dos conflitos no campo foram irrisórios durante o século XX, se comparados com outras unidades da federação. Entretanto, a partir de 2001 inicia-se um crescimento exponencial dos conflitos no campo, como pode ser observado no Gráfico 1, o que demonstra o papel das redes técnicas implantadas pelo Pac como indutoras dos conflitos, na medida em que há a penetração do grande capital no campo. 
Gráfico 1: Conflitos no campo - Amapá (1985-2017)

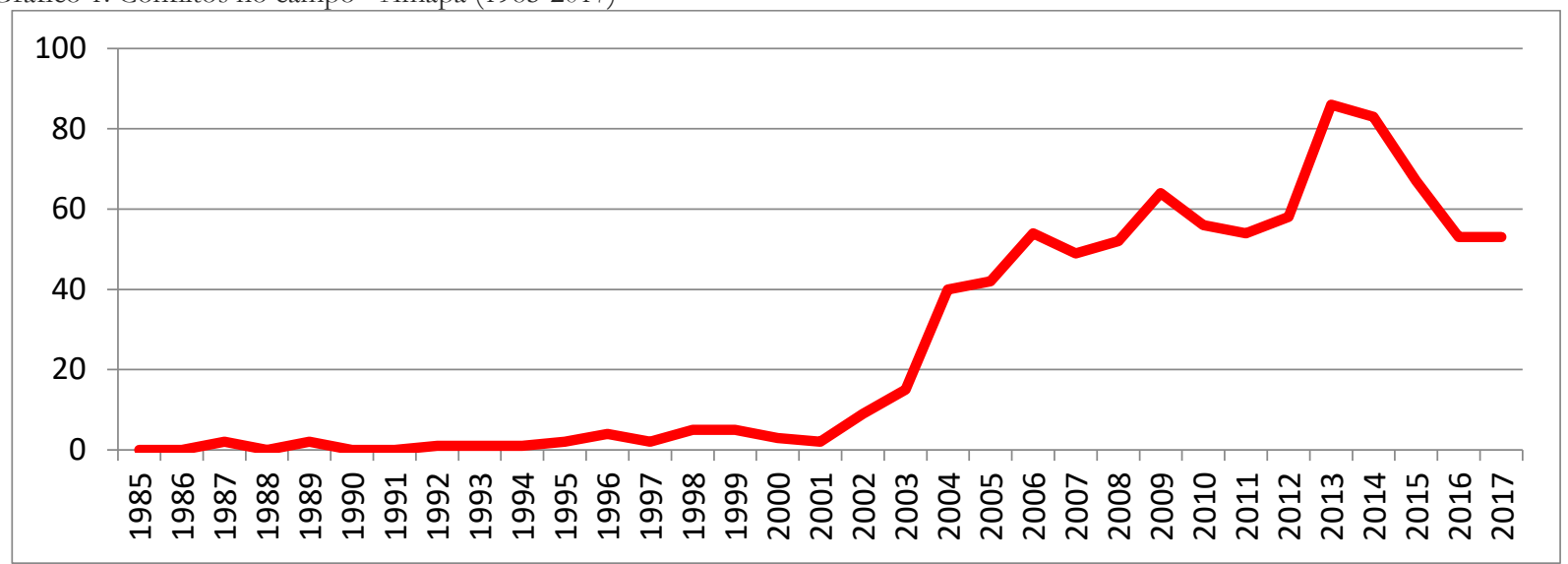

Fonte: CPT (1985-2017).

Organização: Pinto-Miranda, 2019.

Elaboração: Margarit, 2019.

Ainda sobre os dados dos conflitos no campo no Amapá também é necessário destacar o agravamento do número de conflitos entre 2012 e 2014, período em que é implantada a infraestrutura de exportação de grãos no Porto de Santana e inicia-se o cultivo de soja no Amapá.

\section{CONSIDERAÇÕES FINAIS}

Espera-se ter evidenciado suficientemente os mecanismos de consenso e coerção em torno do projeto de desenvolvimento hegemônico no estado do Amapá. A dinâmica coercitiva se faz ainda por meio da perseguição aos movimentos ambientalistas e indigenistas, oposição política, intelectuais, e todos os que lutam para a defesa do meio ambiente e dos povos tradicionais. Essa perseguição ocorre sob argumentos progressistas e desenvolvimentistas em torno de um pretenso "bem comum". A ofensiva da ideologia liberal extremista se baseia na violência declarada como mecanismo de coerção aos interesses da nação, que na verdade não passam de interesses hegemônicos camuflados como interesses nacionais. Esta retórica foi inflamada com a eleição do presidente Jair Bolsonaro, em 2018, fortalecendo grupos liberais extremistas em todo o País.

Contudo, cabe destacar que instrumentos violentos de coerção do Estado não são mecanismos novos na manutenção do poder e efetivação dos interesses hegemônicos. O contexto pós 2018 simboliza apenas um momento extremista do poder hegemônico. As grandes obras de infraestrutura do Pac na Amazônia foram, desde o início, objeto de subjugação de povos tradicionais pela violência. O maior símbolo do poder coercitivo do Estado foi a UHE Belo Monte. Sob o argumento da necessidade de produção de energia para o desenvolvimento do país o Estado cometeu atrocidades contra os povos tradicionais e implantou um dos regimes mais violentos de violação dos direitos humanos, utilizando de instrumentos da Ditadura Militar, como o mecanismo de suspensão de segurança, uso intensivo de forças armadas e violação de tratados internacionais para assegurar a construção do empreendimento ${ }^{3}$.

Por fim, é importante reafirmar aqui a necessidade de se pensar a Amazônia a partir da Amazônia, para que ela não continue exercendo o papel histórico de fonte de recursos e exploração econômica para o enriquecimento das elites capitalistas. Há muitas alternativas ao modelo de desenvolvimento hegemônico no Amapá e para concebê-las basta o olhar atenci- 
oso ao seu povo.

NOTAS

1 Pesquisa financiada pela Coordenação de Aperfeiçoamento de Pessoal de Nível Superior (Capes) (2016-2018).

2 Informação oral proveniente dos entrevistados R. S. M., E. S. M., A. O. C., F. E. S., A. P. S. e R. A. S. M. (2017) e M. C. C. (2018).

3 As armadilhas do discurso que envolve o processo de implantação de usinas hidrelétricas na Amazônia e os mecanismos de violação de direitos foram abordadas mais amplamente por Margarit (2013).

\section{REFERÊNCIAS}

AMAPÁ. Lei n. 1.981, de 15 de janeiro de 2016. Institui o Plano Plurianual para o quadriênio 2016-2019 e dá outras providências. Diário Oficial do Estado do Amapá, Macapá, AP, 15 jan. 2016. Disponível em: <http://seplan.ap.gov.br/interno.php?dm=530>. Acesso em: 10 jan. 2019.

CPT, Comissão Pastoral da Terra. Conflitos no campo (1985-2017). Goiânia: CPT, 19852017. Disponível em: <http://www.cptnacional.org.br/index.php/publicacoes-2/conflitosno-campo-brasil >. Acesso em: 31 jan. 2019.

GRAMSCI, Antonio. Cadernos do cárcere. 3. ed. Rio de Janeiro: Civilização brasileira, 2004. (v. 2)

GRAMSCI, Antonio. Cadernos do cárcere. 3. ed. Rio de Janeiro: Civilização brasileira, 2007. (v. 3)

MARGARIT, Eduardo. As armadilhas do discurso que envolve o processo de implantação de usinas hidrelétricas na Amazônia. Ciência Geográfica. Bauru, vol. XVII, nº 1, Jan.-Dez. 2013. p. 150-163.

MONTEIRO, Juan. AP sobe nove posições no Ranking de Competitividade dos Estados. Macapá: Aprosoja, 04 ago. 2017. Disponível em: <https://aprosojaap.com.br/2017/ 08/amapa-cresce-nove-posicoes-no-ranking-de-competitividade-dos-estados-brasileiros2/>. Acesso em: 30 jan. 2018.

SANTOS, Milton; SILVEIRA, Maria Laura. O Brasil: território e sociedade no início do século XXI. 9. ed. Rio de Janeiro: Record, 2006. 